\title{
How to fight long-term unemployment: lessons from Germany
}

\author{
Alexander Spermann
}

Correspondence: spermann@iza.org IZA and University of Freiburg, Postfach 7240, 53072 Bonn,

Germany

\begin{abstract}
The number of long-term unemployed in Germany has stagnated at around one million for several years. Despite excellent labour market conditions, the long-term unemployment rate is well above the OECD average. Therefore, the "carrot and stick" principle of Hartz reforms is in clear need of further development. The author proposes an overall concept for preventing and reducing long-term unemployment and longterm basic income receipt. An important element is an activation strategy for the longterm unemployed and long-term basic income recipients that implies interim target setting and requires more and better trained case managers in the job centres.
\end{abstract}

Jel codes: $\mathrm{J} 31 ; \mathrm{J} 38$

Keywords: Long-term unemployment; Long-term basic income receipt; Germany; Training programmes; Active labor market policy; Activation

\section{Introduction}

The German labour market has changed drastically over the last ten years. Just a decade ago there was mass unemployment with roughly five million unemployed people and low employment rates. Germany was labelled "the sick man in Europe". Today, unemployment is well below the three million threshold and employment rates are at a record high. Germany has been dubbed a job wonderland and European champion with regard to its labour market (see Rinne and Zimmermann 2013 and Dustmann et al. 2014).

Against this backdrop, it is time to reflect on the further development of the basic income system in Germany. It is indeed true that the Hartz reforms, which are considered internationally as the largest labour market reforms in post-war history, led to a clear decline in the number of unemployed and long-term unemployed people; however, the interim reports after five and eight years of the Hartz IV reform (see Koch et al. 2009 and Dietz et al. 2013) clearly show that the problem of long-term unemployment and long-term basic income receipt remains unsolved. Roughly one million people have remained unemployed for longer than one year and are therefore considered long-term unemployed. Approximately three million employable individuals received basic income for about two years or longer and are considered long-term basic income recipients. Note that the 2005 Hartz IV reform as a part of the Hartz reforms refers to the merger of unemployment assistance and public assistance to one means-tested and tax-financed basic income scheme which allowed previous public assistance recipients access to active

(c) 2015 Spermann. This is an Open Access article distributed under the terms of the Creative Commons Attribution License (http:// creativecommons.org/licenses/by/4.0), which permits unrestricted use, distribution, and reproduction in any medium, provided the original work is properly credited. 
labour market policy instruments. Therefore, the "carrot and stick" principle of the Hartz reforms is in clear need for further development.

The paper is structured as follows. In chapter 2, empirical evidence with a focus on long-term unemployment will be summarised following a depiction of long-term unemployment and long-term basic income receipt. Chapter 3 serves to shed light on the practice of "carrot and stick". In Chapter 4, a differentiated three-pillar concept for preventing and reducing long-term unemployment and long-term basic income receipt will be outlined on the basis of different experiences with Hartz IV over the last ten years. A conclusion to this issue is given in Chapter 5 .

\section{Long-term unemployment and long-term basic income receipt in Germany}

In Germany, people who are unemployed longer than 12 months are considered long-term unemployed. Between 2005 and 2011, the number of long-term unemployed people decreased considerably from roughly 1.8 million to roughly 1 million. Since then, the number of long-term unemployed has remained largely unchanged, as illustrated by Fig. 1.

In January 2015, the number of long-term unemployed totalled 1.074 million. The fraction of long-term unemployed in relation to the total number of unemployed people decreased slightly to $35.4 \%$ in comparison with January 2014 (see Federal Employment Agency 2015a).

The long-term unemployed receive either tax-financed and means-tested basic income (i.e. Hartz IV) or social security contribution-financed unemployment benefits. More than ninety per cent of the long-term unemployed are Hartz IV-recipients. Only almost ten per cent of the long-term unemployed receive unemployment benefits.

The dynamics behind the stock of long-term unemployed of about one million deserves further analysis. In January 2014, the stock of long-term unemployed was excactly 1,062,484. Throughout the year 2014, 784,738 short-term unemployed became long-term unemployed (inflow) and 809,916 terminated their long-term unemployment

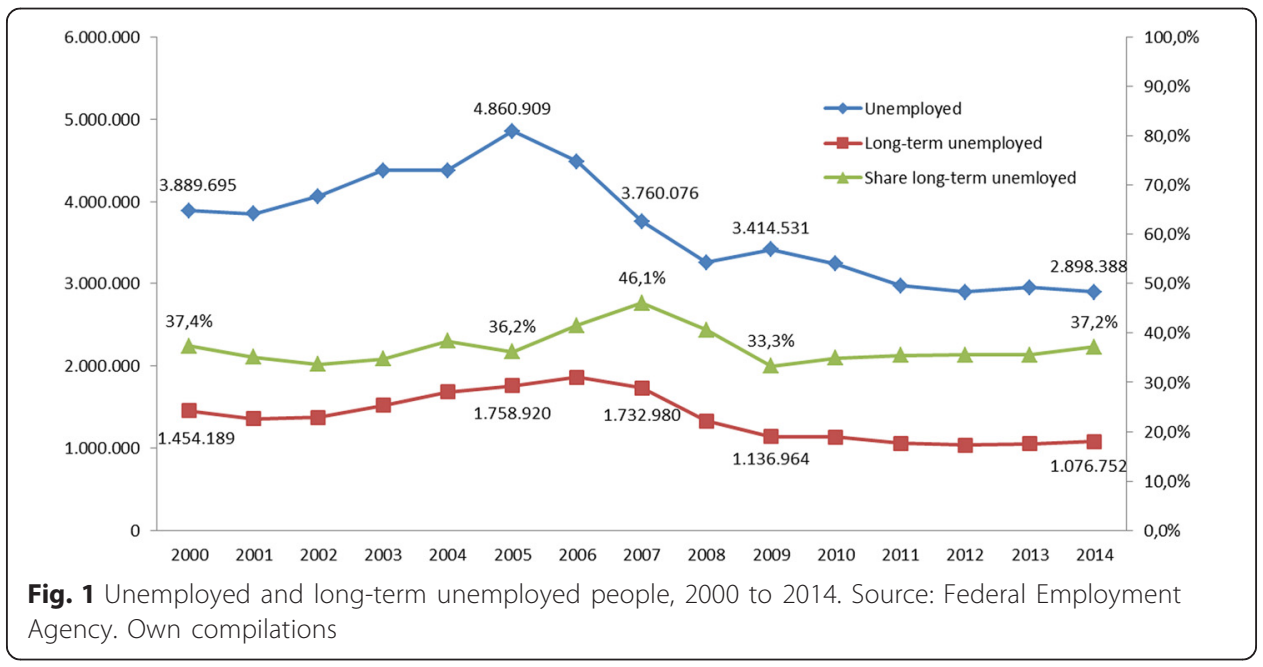


spell (outflow) so that the stock number declined to $1,037,306$. However, just $25 \%$ of the outflowing of the long-term unemployed (i.e. less than 200,000) were employed or self-employed and only $16 \%$ participated in education programmes. In the event that they were employed just for one day or took part in job creation schemes for longer than six weeks, the duration of unemployment is reset (see Federal Employment Agency 2015b). As a result, the problem tends to be underestimated.

Therefore, figures based on surveys conducted by the OECD are better able to demonstrate the scale of the problem (see Junankar PN Raja 2011). According to the OECD statistics, Germany is a country with a very high long-term unemployment rate. With a rate of $45 \%$, Germany is ten per cent over the OECD member state average (see OECD 2014).

A specific feature of the German Hartz IV basic income system is that recipients have to be able to work at least three hours per day. As a consequence, long-term basic income recipients that are not registered as unemployed (e.g. single parents due to childcare) may receive Hartz IV. In 2013, the annual average of Hartz IV basic income recipients totalled 4.42 million, of which 2.52 million were not unemployed, 1.02 million were short-term unemployed and 881,000 were long-term unemployed. For our discussion: The Public Employment Service defines Hartz IV long-term basic income receipt slightly different: In the same year, 3.123 million were long-term basic income recipients who had been receiving Hartz IV for at least 21 months in the last 2 years. Therefore, the policy relevant group are not just the long-term unemployed but the larger group of long-term basic income recipients. Note that there is still a basic income system for disabled people who are not able to work at least three hours per day.

Risk factors for long-term unemployment older age and lack of vocational training. Almost half of unemployed older people over the age of 55 are long-term unemployed, of which more than one fourth has been long-term unemployed for a very long time (more than two years). With respect to vocational training: Almost 52\% of all long-term unemployed people have not completed any vocational training (see Federal Employment Agency 2014a). Health issues and family status (couples with children and single parents) also play an important role for the long-term basic income recipients (see Graf 2007, Graf and Rudolph 2009, Dietz et al. 2013, Koller-Bösel et al. 2014).

Barriers such as older age and health issues are often present at the same time. Multiple barriers are therefore particularly problematic because the probability of transition to employment is cut by almost half if you add one more risk (see Achatz and Trappmann 2011).

Supporting evidence for scarring effects of long-term unemployment comes from a field experiment conducted in the U.S.. Kroft et al. (2013) find adverse effects of a longer unemployment spell, i.e. negative duration dependence. Long-term unemployment not only reduces employability and the probability of being employed in the future, but also causes people to become lonely and sick. The loss of a social network through job loss brings about an unexpected shock, which can even cause otherwise confident people to become insecure when applying for jobs for which they are over-qualified. Hundreds of unsuccessful applications lead to feelings of discouragement, worthlessness as well as lack of prospects and even depression (see Winkelmann and Winkelmann 1998, Böckerman and Ilmakunnas 2009, Knabe et al. 2010). It is therefore seen as positive that the Federal Minister of Labour and the Federal Employment Agency now want to intensively address the issues of long-term unemployment and long-term basic income receipt. 


\section{The German "carrot and stick" ("fördern und fordern") principle in practice}

\subsection{Sufficient and qualified personnel in the job centres}

Some core institutional features of the complicated German system have to be mentioned beforehand. First, short-term unemployed who receive social security contribution financed unemployment benefits are clients of job placement officers in 156 regional employment offices. Second, the means-tested long-term unemployed who receive taxfinanced basic income (i.e. Hartz IV) are clients of case managers in 413 job centres. Both regional employment offices and 303 job centres are part of the Federal Employment Agency in Nuremberg. In addition to these 303 job centers, 110 job centres are under local management by municipalities thereby being more independent of Nuremberg.

Having sufficient and qualified personnel in the employment agencies and job centres is a prerequisite to successfully implementing active labour market policy tools. This is confirmed by comprehensive empirical evidence (see Rosholm 2014). In Germany, job placement officers in public employment services had to deal with up to 800 unemployed in the nineties. Empirical studies with comparison groups using Propensity Score Matching to solve the fundamental evaluation problem showed that a relationship of 1:60 allows job placement officers to do a better job: It turned out that the job placement probability of the treated was 15.31 percentage points higher (see Jerger et al. 2001). These results induced policymakers to invest in job placement officers as a part of the Hartz reforms.

However, case managers in job centres have currently been overloaded with dealing with the long-term unemployed with multiple job placement risks such as health and debt issues, especially in regions with a high density of long-term unemployed. Therefore, a recent project was implemented by the Berlin-Brandenburg Public Employment Services in twelve job centres between 2011 and 2013. For the purposes of the project, one case manager had to care only for about 100 Hartz IV basic income recipients. A descriptive analysis without a control group showed that 22,000 people took up jobs subject to social security contributions which led to 22 million euros of fiscal savings (see Federal Employment Agency 2014b, pg. 27 and Egenolf et al. 2014).

\subsection{What works?}

In international literature a distinction is typically made between four types of active labour market policy instruments (see Boeri and van Ours 2013, Cahuc et al. 2014): support with the job search, further training, wage subsidies and public job creation schemes. A macro meta-analysis by Martin (2015) illustrates that the joint effect of all active labour market instruments is significantly negative with respect to unemployment. A micro metaanalysis by Card et al. (2010) shows that the overall labour market policy has a significantly positive and long-term influence on individual employment prospects.

On a national level, Kluve (2013) shows that providing job search assistance has a shortterm, positive effect and is cost-effective, whereas further training has a negative short-term effect but was, however, positive in the long run. Wage subsidies have a short-term positive effect, however, the long-term effects are still unclear due to possible indirect influences. Job creation schemes have both a short-term and long-term negative influence on the employment prospects for the unemployed. However, the expenditures and participant numbers for active labour market policy instruments have been dwindling for some years. 
Overviews of the German evaluation studies on active labour market policies after the Hartz reforms are provided by Jacobi and Kluve (2006), Eichhorst and Zimmermann (2007), Heyer et al. (2012) and Wolff and Stephan (2013). The following tools have been positively evaluated with respect to improvements of the reemployment prospects of unemployed people (see Achatz et al. 2012, Bernhard and Kruppe 2012, Brussig et al. 2011, Knuth et al. 2014, Königs 2014): employer subsidies, job placement vouchers (see Winterhager et al. 2006), company-related training measures, training vouchers (Doerr et al. 2014), and the promotion of start-ups (Caliendo and Künn 2011). Overall, Dustmann et al. (2014, p. 184) conclude that the Hartz reforms have contributed to the decline in long-term unemployment.

In-work benefits as an element of the German basic income scheme have also been subject to scientific and public debate under the heading "combi-wage model" for over a decade (see Sachverständigenrat zur Begutachtung der gesamtwirtschaftlichen Entwicklung (2006) and Dietz et al. 2013). Policy proposals that focused on lower basic income level and lower benefit reduction rates (BRR) to incentivize basic income recipients were rejected by all political parties. Implementing low BRRs into a high basic income level would create additional basic income recipients, thereby boosting fiscal expenditures. For example, a benefit reduction rate of $50 \%$ would provide a high incentive to work; however, it would also cause the tax-exempt income to double resulting in a large number of former taxpayers becoming basic income recipients. The German solution takes this trade-off into account: Below net income of $100 €$, the BRR is zero, between 100 and $800 €$, it jumps to $80 \%$, between 800 and $1200 €$, it slightly increases to $90 \%$, and beyond the BRR equals 100\% (see Dietz et al. 2009). Nevertheless, Cremer (2013) summarizes the situation as follows: "The in-work benefit regulation is very useful, not to say a social achievement".

Furthermore, temporary in-work support via earnings disregards and supplementary basic income schemes have proven to be successful by randomized controlled trials in Canada (see Michalopoulos 2005) and by a quasi-experiment in Germany (see Spermann and Strotmann 2005). A temporary in-work benefit for the long-term unemployed (Einstiegsgeld) became a standard active labour market instrument in Germany in 2005 and has been positively evaluated several times (Dietz et al. 2013). However, the Canadian experience showed that the initially positive treatment effect faded out after a while (see Card and Hyslop 2005).

Combining temporary in-work support with a post-employment component has turned out to be successful with respect to sustainable employment of previous welfare recipients and the long-term unemployed. The Canadian Self Sufficiency Program Plus, a programme for single-parent welfare recipients, found sustained effects with an increased employment rate averaging nearly 7 percentage points 36-52 months after randomisation in comparison with a programme that provided financial in-work benefits alone (see Robins et al. 2008 and Dorsett 2014). The UK Employment Retention and Advancement (ERA) programme used a randomized controlled trial-one of largest ever undertaken in Britain-to identify the causal effect. The treatment was a package of financial incentives such as earnings supplements for taking-up a full-time job, an employment retention bonus, tuition assistance for training courses as well as adviser support. The treated long-term unemployed had a 2.2 percentage point higher probability of working five years after randomization than the controls. Furthermore, ERA proved 
cost-effective for the long-term unemployed from the perspectives of the participants themselves, the Government budget, and society as a whole (see Hendra et al. 2011 and Dorsett 2014). These results give guidance based on hard evidence for the further development of German active labour market policy.

\subsection{Current pilot projects}

\subsubsection{Employer subsidies plus coaching}

In 2012/2013, several pilot projects in three states such as Rhineland-Palatinate, North Rhine-Westphalia and Baden-Wuerttemberg have been started. These projects were predecessors of a 900 million euro programme launched by the Federal Minister of Labour in 2014 and rolled out nationwide in 2015 (see Federal Ministry of Labour and Social Affairs 2014).

In a nutshell, these projects combine up to $100 \%$ employer subsidies with coaching for the very long-term unemployed (Federal Employment Agency 2013a, 2013b). What is new about this approach is that the very long-term unemployed are encouraged to take up jobs with permanent contracts subject to social security contributions primarily in private companies.

Participants in Rhineland-Palatinate and North Rhine-Westphalia pilot projects are long-term unemployed (with a duration of unemployment of over two years) over the age of 35 who lack professional qualifications and have health issues. Moreover, active labour market policy instruments have not been proven successful and that obtaining employment within 12 months was predicted as being unlikely. The pilot project is planned to last three years with 40 participants. Conditional on a permanent contract with a private company, the Federal Employment Agency subsidises $75 \%$ of the wage costs for three years. Additionally, it covers the full costs for company coaches. According to the Federal Employment Agency, 37 of the 40 long-term unemployed people were successfully integrated (see Federal Employment Agency 2014c).

Conceptionally, the Baden-Wuerttemberg pilot project deviates just in details (see Ministry for Social Affairs Baden-Wuerttemberg 2012); however, it was designed for 570 participants and subject to scientific evaluation. The first descriptive evaluation results show that more than half of the previously long-term unemployed are now employed in the private sector and the remaining individuals employed in agencies. An employer survey reveals what will probably happen after employer subsidies have run out. Almost half of the private companies and only just a fourth of publicly funded companies plan to continue the employment relationship. A causal analysis based on Propensity Score Matching is a work in progress (see ISG/IAB 2014).

\subsubsection{Education programmes}

The German dual education system combines apprenticeships in companies with general training provided by training institutions (see Boeri and van Ours 2013). A current project launched by the Federal Employment Agency and the Federal Government in 2013 is aimed primarily at young unemployed people ( 25 to 35 years in age) without professional qualifications as well as persons returning to the labour force and low qualified individuals. The project's objective is that 100,000 young people take up dual education within three years by intense counselling. By September 2013, 45,000 young people have started an apprenticeship. It is, however, still unclear as to how many of them will complete the dual education (see Federal Employment Agency 2014b). 
As employers primarily pay for dual education, selection of candidates is tough so that applicants have to overcome big obstacles to start an apprenticeship. Therefore, vacancies are not filled although candidates are searching for apprenticeships. One way to solve this mismatch issue might be so-called partial dual education systems. The basic idea is to split up an apprenticeship into standardised and self-contained modules that are individually certifiable. Accumulated modules lead to a partial qualification below the apprenticeship qualification level. This allows low-qualified people to enter the dual education system stepwise. Otherwise, they would have been lost for an apprenticeship opportunity and remained low-qualified. A preliminary descriptive evaluation of the partial dual education system based on small numbers and ignoring the fundamental evaluation problem has been positive (see Federal Employment Agency 2013c, 2014b).

\section{4 "Stick" policy in practice}

The "stick" element of the Hartz reform principle highlights the obligation to work. Public employment (so called "one euro jobs") has been used on a large scale to check whether eligible basic income recipients are willing to work (see Achatz et al. 2012). An integration agreement, in which the job search duties are set down in a written text, was introduced into legislation (see Dietz et al. 2013 and van den Berg et al. 2014). Rules for stepwise sanctions up to a complete benefit withdrawal were implemented to minimize regional variation and to maximize consistency (see Dietz et al. 2013). Numerous empirical studies show that monitoring the job search in combination with sanctions drastically reduces the duration of unemployment and increases the prospects of reemployment for the unemployed (see McVicar 2014). Therefore, sanctions are a useful complement to active labour market policy instruments. Sanction rates in Germany are very low (1.1\%) in comparison to other OECD countries such as the U.S. (35.4\%), The Netherlands (36\%) and the U.K. (5.5\%) as summarised in Boeri and van Ours (2013, p. 353). Boockmann et al. (2014) find that a tighter sanction policy can be quite effective for non-compliant welfare recipients by applying an IV-approach, thereby identifying a local average treatment effect for compliers. This might lead to the conclusion that higher sanction rates could help.

\subsection{More carrots, more sticks?}

In current political debates, both opposition parties are requesting more money, in particular for publicly financed job creation schemes (see www.pothmer.de and German Bundestag 2014a). However, job creation schemes are associated with negative employment effects due to lock-in effects (see Eichhorst/Zimmermann 2007). More of such carrots do not help.

Higher sanctions rates would not solve the issue either if you take bypassing strategies well-known by practictioners into account that are typically not revealed by administrative or survey data. Today, basic income recipients are already taking up so-called mini jobs (social security contribution free jobs with a maximum of 450 euros per month) or even mini-mini jobs (200 euros per month) in order to formally comply with the obligation to work and to maximize net income according to the BRRs (see Dietz et al. 2009). There is also anecdotal evidence of basic income recipients combining both mini jobs and informal labour in the shadow economy. People further circumvent the law by sending standardised applications or attending job interviews yet make it clear to the employer that they 
are not interested in the job being offered. It is also common practice to accept a position only to claim that they are ill via a medical certificate submitted just a few days after starting the job. Empirical evidence on this matter can also be found for temporary work agencies (see Federal Employment Agency 2014d).

As an interim conclusion, it is important to note: Neither more carrots by publicly financed job creation schemes nor higher sanction rates will reduce long-term unemployment. Instead, the "carrot and stick" principle needs further development. This will be discussed in the following chapter.

\section{A differentiated concept for preventing and reducing of long-term unemployment and long-term basic income receipt}

The long-term unemployed and long-term basic income recipients form a heterogeneous group, and it is for this reason that a differentiated concept is required: 'One size does not fit all'. In the following section, a three pillar concept for preventing and reducing longterm unemployment and long-term basic income receipt is proposed. The first pillar highlights prevention of unemployment, the second pillar focuses on minimzing inflow from short-term unemployment and the third pillar is dedicated to maximize outflows to the labour market and education rather than fully subsidised job creation schemes.

\subsection{Pillar 1: prevention is the best kind of medicine}

Early childhood education, completion of school as well as good written and spoken German language abilities lead to the first threshold-the transition between school and vocational training. This transition, however, needs to be more successful in the future, as the lack of professional training is a central risk factor for long-term unemployment. Roughly 1.5 million young people between the ages of 25 and 35 currently have not undertaken any vocational training. This is where the described education programmes come into play.

Prevention also pertains to the partners and children of the long-term unemployed and long-term basic income recipients. "Careers in the basic income system" need to be prevented. Language courses can help to reduce functional illiteracy and thus increase employability. Part-time education could help young mothers and fathers get access to job training. Particular emphasis is placed on enabling people to get training and employment opportunities. However, the supporting infrastructure needs to function even when it comes to part-time education: full-day childcare in day-care centres, kindergartens and schools needs to be ensured. Contact with the labour market can also be created through internships and mentoring for the working population.

\subsection{Pillar 2: minimising inflows from short-term unemployment}

Minimising the inflow rate has been a policy focus of the Hartz reforms. Job placement officers may use all available active labour market policy instruments conditional on budget constraints. Performance-related pay of job placement officers might be an additional route to follow (see Hasnain et al. 2012). However, the heart of the solution most likely lies in professional competency diagnostics by regional employment agency staff. Job placement officers face the challenge of making the short-term unemployed person's strength more suitable and stronger for the labour market and to match these strengths with corresponding job offers in a timely manner. Lastly, job placement 
strategies must be continuously optimised in order to minimise the inflow rate from short-term unemployment (see van den Berg et al. 2014).

\subsection{Pillar 3: maximising outflow to employment and education}

The outflow rate from long-term unemployment to employment and education was just about $40 \%$ in 2014 as reported above. What could be done beyond applying the active labour policy instruments that have proved successful in the past?

First, misleading target setting is one issue. Currently the concept of activation taken by the Federal Ministry of Labour and Social Affairs also allows activation towards a publicly subsidised labour market (so called secondary labour market). The activation ratio for long-term basic income recipients is even explicitly defined as activation in the secondary labour market in the federal strategic controlling system (see Federal Employment Agency 2014b and www.sgb2.info). Such a definition implies incentives for case managers to place long-term unemployed in publicly funded job creation schemes rather than in employment and education.

Second, barriers to take up employment might be too high for the long-term unemployed in the short-run so that attainable interim targets for long-term unemployed people and long-term benefit recipients are to be defined. Moreover, not only the result of the activation-obtaining employment subject to social security contributions or commencing a vocational training programme and further education-but rather the activities aimed at taking up a job are to be understood and valued as the joint success of the case manager and the long-term unemployed or long-term basic income recipient. For this, a wide range of activities should be permitted (i.e. volunteer work, networking and soft skills training).

This interim target setting is illustrated by the following two examples. Example 1: Mr. X is a very long-term unemployed person and has been a long-term basic income recipient without professional qualifications. He has addiction, debt and psychological problems and yet is still fit to work a minimum of three hours daily, thereby receiving basic income (Hartz IV). Active labour market policy instruments used in the past were generally ineffective: Private employers did not want to hire him despite the fact that they would receive employer subsidies. Issued job placement vouchers were not redeemed, self-employment was ruled out, one-euro jobs were ended after a few days due to illness, and he stopped attending education programmes financed with education vouchers after a short period of time. Over several years, he could not be integrated into the labour market, nor was he able to transition into an education programme.

As part of an activation approach, the case manager and Mr. X agree on activities that will help Mr. X reach interim targets. An interim target could be to get his debt and drug problem under control to a point where he at least can be employed. Activities such as consultation appointments with debt and addiction counsellors would be accepted by his case manager as steps towards the interim target. A second interim target to be pursued simultaneously could be social integration. Acitivities such as taking on voluntary work (e.g. in a soup kitchen), taking part in sporting activities (e.g. walking) and networking (e.g. family, friends, Xing groups) would be encouraged by his case manager. Activities bring structure to the day and may enhance skills, e.g. Lechner/ Sari (2014) confirm positive long-run income effects of sports activities estimating doseresponse relationships. The third interim target—increasing employability—can only be 
set once the more pressing personal problems have been solved. Soft skills training and mobile learning could also be good activities.

Example 2: Ms. Y is a low-qualified, single mother of two children with health and self-confidence problems, high immobility due to her caring responsibilities-she is not long-term unemployed; however, she is a long-term basic income recipient. Due to her obligations at home, traditional labour market policy tools are not very effective. Furthermore, outflow from the basic income system is only possible with a very high net income. However, a net income of 900 euros is enough to no longer be dependent on basic income. This is ensured by the so-called child allowance (see Federal Employment Agency 2014e). Against this backdrop, the first interim target to removing employment barriers could be organising childcare and obtaining psychological support. These would be appropriate activities to increase self-esteem. Answering questions pertaining to career orientation (What do I want to do?) and qualification programmes (What training do I want to receive?) could be an additional interim target. Profiling (analysis of strengths and weaknesses) and training measures could be suitable activities for this purpose. Completing an internship (possibly as part of a education programme) and taking on a mini-job could be the following steps. These activities have to lead towards employment in the long-run.

The same logic applies to education programmes. The partial dual education system allows for a stepwise approach. However, placing the focus solely on education programmes ending with certified qualifications does not fully reflect labour demand. There is an increased demand for special skills (hard and soft skills) on the labour market, which can at least be partially obtained without attending education programmes that last several years. Mobile learning and online competency tests open the door to significantly more relevant training programmes. The German Qualification Framework for Lifelong Learning is the point of departure for skill building and could be further developed to automatically certify qualification through the acquisition of credit points in the near future (see Spermann 2014).

\section{Discussion}

\subsection{Has an activation approach already been implemented in Germany?}

In 2009, the Federal Employment Agency implemented a four-phase integration model (4PM). In 2013, the key concepts and practical tools were updated-corresponding guidelines (HEGA 12/13-10) have been in effect since 20.12.2013. The four-phase integration model, the SGB II consultation concept and the competency services from Vocational Psychology Services are complements of the Federal Employment Agency's approach. Profiling with the help of competency diagnostic is executed as part of the four-phase model (Phase 1: Situational analysis). Targets are then established (Phase $2=$ Target-setting). Lastly, strategies are selected (Phase 3: Solution-oriented strategies) before agreements are implemented and monitored (Phase 4). The start-date is established in the integration agreement between the unemployed and the job placement officer in the regional employment offices as well as between case managers and the long-term unemployed in the job centres. Discussions and individual integration plans are documented in the consultation notes. Action strategies with interim targets leading towards a gradual integration into the labour market are also formulated. Structured follow-up discussions and follow-up notes 
are key elements to the implementation. Scheduling appointments takes place after the contact building component (see Federal Employment Agency 2014f, g, h).

At first glance, it would seem as though the proposed activation approach has been already implemented; however, for several reasons it is not. First: Although the four-phase model was already implemented in 2009, Dietz et al. (2013) ascertained that people with multiple job placement risks have the lowest number of contacts with their case manager. This reflects an underinvestment in case management. Second: even if the quantity and quality of case managers were sufficient, there is an obvious shortage of social integration services. According to estimates for 2013, 25\% of employable basic income recipients have debt problems, $10 \%$ have addiction problems and 20\% require psychosocial support. By contrast, no more than one fourth of these people received appropriate counselling services (see Kaltenborn/Kaps 2012). In the event that the required debt, addiction or psychosocial consultation is not available to achieve an interim target, this target will not be achieved. Third: although further training for case managers has started, only a minority of job centres' case managers have been certified so far. There is clear need for investment in their training. Fourth: over the past few years, the high share of fixed-term contracts for case managers has led to extremely high staff turnover in the job centres. As a result, interim target setting and coaching has been an exception in practice so far. In the meantime, the ratio of fixed-term contracts has dropped to under ten per cent on average (see German Bundestag 2014b). However, media reports reveal work overload in regions with a high concentration of long-term unemployed, resulting in high regional staff turnover.

\subsection{Success factors for an activation approach}

1. Number of case managers

Case managers are key to the success of an activation approach. Therefore, case managers need time to effectively counsel and coach the long-term unemployed. A better ratio of case managers to long-term unemployed/long-term basic income recipients is an investment in better support. Case managers would therefore need to be hired on a larger scale.

2. Case manager's further training In addition to quantity, the quality of the case manager is also a crucial factor for successful activation. Certified further training of case managers has been implemented in principle. However, due to job centres' budget constraints, a nationwide rollout is far from reality. An important issue is the quite difficult role of case managers because he/she is perceived as a representative of the authority that grants basic income. Building trust is therefore required; however, previous experience shows that this needs sufficient time for counselling and coaching (see Knuth et al. 2014 and Boockmann/Brändle 2015).

3. The availability of social integration services The nationwide availability of addiction, debt and psychosocial counsellors (social integration services) is a large problem. On top of that, just two thirds of the job centres give data on the social integration benefits to the Federal Employment 
Agency - to this effect, there is a lack of transparency regarding the available regional social integration benefits (see Adamy/Zavlaris 2014).

If, after years of intense activation, individuals are not successfully integrated in the labour market, then employability is not a realistic target anymore. In these cases, it would make sense to obtain further support from other legal systems such as the basic income system for the disabled or handicapped. In such a case, employment rehabilitation service tools and social policy schemes are available rather than active labour market policy instruments.

\section{Conclusion}

Despite the fact that employment in Germany rose by 43 million and unemployment dropped to 2.7 million by the end of 2014, ten years after the Hartz IV reforms, long-term unemployment and long-term basic income receipt is a major issue in the German labour policy debate. At that time, a definition of employability that is very broad by international comparison was selected: Individuals who can work at least three hours per day are considered employable. Experience with the "carrot and stick" principle of the Hartz reforms has proven that institutional reforms and some of the active labour market policy instruments are beneficial and contributed to the reduction of long-term unemployment. Nevertheless, the number of long-term unemployed people remained largely unchanged at roughly one million over the last few years.

The high risk factors for long-term unemployment are lack of professional qualifications and age. Health issues and family status also play an important role when comes to longterm basic income receipt: 3.1 million individuals were classified as long-term basic income recipients in 2013.

In a weakening economy, the problem of long-term unemployment and long-term basic income receipt is likely to increase. Furthermore, if the concerns of many labour market economists are true with respect to the introduction of a statutory minimum wage of EUR 8.50 per hour, the number of long-term unemployed people without professional qualification will surge more than ever before. Although the long-term unemployed are exempt from the minimum wage for the first six months of a new employment relationship, this time period seems rather short. Against this background, it is all the more important for the federal government and the Federal Employment Agency to give precedence to further reducing long-term unemployment and long-term basic income receipt.

A differentiated concept for preventing and reducing long-term unemployment and long-term basic income receipt was brought forward. This concept consists of three pillars: Prevention of unemployment (pillar 1), minimising the inflow rate from short-term unemployment (pillar 2) and maximising the outflow rate to employment and education (pillar 3).

The activation approach taken in pillar 3 reflects the necessary further development of the "carrot and stick" principle. Unlike the first ten years of Hartz IV, interim targets should be set to allow a stepwise integration of the long-term unemployed and longterm basic income recipients into the labour market. Activation should lead to activities towards taking up jobs and retaining them rather than taking up subsidised public jobs. This is why target setting by the Federal Ministry of Labour and Social Affairs should be modified appropriately. Furthermore, the spirit should be different: Case managers should 
appreciate individual's efforts to reach interim targets. Actions aimed at joining the labour market in the long run are to be supported (e.g. voluntary work to build up potential networks, acquiring soft skill training or even sports activities). This is how a trusting relationship can be built between the long-term unemployed and their case managers.

On a societal level, there needs to be a stable consensus regarding the basic income system: if the long-term unemployed and long-term basic income recipients are able to show efforts towards a long-run integration into the labour market, the feeling of altruism amongst taxpayers could be strengthened (see Solow 1998).

A successful implementation of the proposed three pillar concept requires investment in education, labour market policy and social policy. Prevention of unemployment primarily needs educational investments. More and better-educated case managers are a precondition for implementing an activiation approach. Furthermore, social integration services (addiction, debt and psychosocial counselling) should be available nationwide. Continuous scientific evaluation reduces the risk of negative returns on investment. International evidence from the UK shows that a well-designed package for supporting the long-term unemployed could be cost-effective.

\section{Competing interest}

The IZA Journal of Labor Policy is committed to the IZA Guiding Principles of Research Integrity. The author declares that he has observed these principles.

\footnotetext{
Acknowledgement

The author would like to thank two referees and the editor for detailed comments. Comments by participants in meetings held in Dresden on 25 September 2014 by the Committee for Social Policy of the German Economic Association, in particular the co-speaker, Ulrich Walwei (IAB), are appreciated. I would also like to thank the participants of the 11th IWH/IAB workshop on labour market policy held in Halle on 2 October 2014, the participants of the IZA Brownbag seminar held in Bonn on 29 October 2014 and the IZA conference, "10 years of Hartz IV-what really helps the long-term unemployed?" held in Berlin on 20 November 2014 as well as Werner Eichhorst, Hermann Genz, Christian Rauch, Markus Schmitz and Klaus F. Zimmermann for their helpful comments as well as Ximeng Fang and Radost Holler for their research assistance. Responsible editor: Richard Hendra
}

Received: 8 January 2015 Accepted: 29 May 2015

Published online: 10 August 2015

\section{References}

Achatz J, Trappmann M (2011) Arbeitsmarktvermittelte Abgänge aus der Grundsicherung: Der Einfluss von personen- und haushaltsgebundenen Arbeitsmarktbarrieren. IAB Discussion Paper 2/2011, Nuremberg

Achatz J, Fehr S, Schels B, Wolff J (2012) Ein-Euro-Jobs, betriebliche und schulische Trainingsmaßnahmen: Wovon junge Arbeitslose im SGB II am meisten profitieren. IAB Short Report 6/2012, Nuremberg

Adamy W, Zavlaris E (2014) Sozialintegrative Leistungen der Kommunen im Hartz-IV-System, Arbeitsmarkt aktuell Nr. 1. Bernhard S, Kruppe T (2012) Effectiveness of further vocational training in Germany - Empirical findings for persons receiving means-tested unemployment benefit. IAB Discussion Paper 10/2012, Nuremberg

Böckerman P, Ilmakunnas P (2009) Unemployment and self-assessed health: evidence from panel data. Health Econ 18:161-179. doi:10.1002/hec.1361

Boeri T, van Ours J (2013) The economics of imperfect labor markets, 2nd edn. Princeton University Press, Princeton

Boockmann B, Brändle T (2015) Coaching, counseling, case- working: Do they help older unemployed out of benefits and back into the labor market?. IZA Discussion Paper No. 8811, Bonn

Boockmann B, Thomsen S.L., Walter T (2014) Intensifying the use of benefit sanctions: an effective tool to increase employment?, IZA J of Labor Policy 3:2. http://www.izajolp.com/content/pdf/2193-9004-3-21.pdf. Accessed 14 May 2015

Brussig M, Schwarzkopf M, Stephan G (2011) Eingliederungszuschüsse - Bewährtes Instrument mit zu vielen Varianten. IAB Short Report 12/2011, Nuremberg

Cahuc P, Carcillo S, Zylberberg A (2014) Labor economics, 2nd edn. MIT Press, Cambridge

Caliendo M, Künn SK (2011) Start-Up Subsidies for the Unemployed: Long-Term Evidence and Effect Heterogeneity. J Pub E 95:311-331

Card D, Hyslop DR (2005) Estimating the effects of a time-limited earnings subsidy for welfare-leavers. Econometrica 73:1723-1770

Card D, Kluve J, Weber A (2010) Active labor market policy evaluations: A meta-analysis. Econ J 120:452-477. doi:10.1111/j.1468-0297.2010.02387.x

Cremer G (2013) Was hilft gegen Armut? Ein Essay von Georg Cremer. Soziale Arbeit kontrovers 7. Lambertus-Verlag, Freiburg

Dietz M, Müller G, Trappmann M (2009) Warum Aufstocker trotz Arbeit bedürftig bleiben. IAB Kurzbericht 2/2009, Nuremberg 
Dietz M, Kupka P, Lobato PR (2013) Acht Jahre Grundsicherung für Arbeitsuchende: Strukturen - Prozesse - Wirkungen. IAB Library 347, Bielefeld

Doerr A, Fitzenberger B, Kruppe T, Paul M, Strittmatter A (2014) Employment and earnings effects of awarding training vouchers in Germany. ZEW Discussion Paper No. 14-065. Mannheim

Dorsett R (2014) The effect of temporary in-work support on employment retention: Evidence from a field experiment. Labour Econ 31:61-71

Dustmann C, Fitzenberger B, Schönberg U, Spitz-Oener A (2014) From Sick Man of Europe to Economic Superstar: Germany's Resurgent Economy. JEP 28:67-188

Egenolf D,Fertig M, Hunger K, Puxi M, Rosemann M, Weimann M (2014) Implementationsstudie zur Berliner Joboffensive, IAB-Forschungsbericht 1/2014

Eichhorst W, Zimmermann KF (2007) And then there were four... How many (and which) measures of active labor market policy do we still need? Appl Econ Q 53(3):243-272

Federal Employment Agency (2013a) Eingliederungsbericht 2012, Nuremberg

Federal Employment Agency (2013b) Perspektiven in Betrieben: ein neues Angebot für marktferne Kunden. Regionaldirektion Nordrhein-Westfalen, Düsseldorf

Federal Employment Agency (2013c) BA-Projekt, "Optimierung der Qualifizierungsangebote für gering qualifizierte Arbeitslose", Abschlussbericht Mai 2013, Nuremberg

Federal Employment Agency (2014a) Der Arbeitsmarkt in Deutschland - Die Arbeitsmarktsituation von langzeitarbeitslosen Menschen, Nuremberg

Federal Employment Agency (2014b) Grundsicherung für Arbeitssuchende, Jahresbericht 2013, Nuremberg

Federal Employment Agency (2014c) Press release 25/07/2014. http://www.arbeitsagentur.de/web/content/EN/Press/ Detail/index.htm?dfContentld=L6019022DSTBAl675333. Accessed 16 April 2015

Federal Employment Agency (2014d) Der Arbeitsmarkt in Deutschland - Zeitarbeit - Aktuelle Entwicklungen, Nuremberg

Federal Employment Agency (2014e) Merkblatt Kinderzuschlag, Nuremberg

Federal Employment Agency (2014f) Das arbeitnehmerorientierte Integrationskonzept der Bundesagentur für Arbeit (SGB II und SGB III), 20.12.2013

Federal Employment Agency (2014g) Beratungskonzeption SGB II, Nuremberg

Federal Employment Agency (2014h) Dienstleistungen zur Kompetenzfeststellung, Nuremberg

Federal Employment Agency (2015a) Der Arbeits- und Ausbildungsmarkt in Deutschland - Monatsbericht Januar 2015, Nuremberg

Federal Employment Agency (2015b) Stock-Flow-Analyse der Langzeitarbeitslosigkeit, Nuremberg

Federal Ministry of Labour and Social Affairs (2014) Chancen eröffnen - soziale Teilhabe sichern: Konzept zum Abbau der Langzeitarbeitslosigkeit, 5.11.2014

German Bundestag (2014a) Fünf-Punkte-Programm zur Bekämpfung und Vermeidung von Langzeiterwerbslosigkeit. Drucksache 18/3146, Berlin

German Bundestag (2014b) Befristete Beschäftigung in Jobcentern. Drucksache 18/3093, Berlin

Graf T (2007) Bedarfsgemeinschaften 2005 und 2006 - Die Hälfte war zwei Jahre lang durchgehend bedürftig. IAB Short Report 17/2007, Nuremberg

Graf T, Rudolph T (2009) Dynamik im SGB II 2005-2007 - Viele Bedarfsgemeinschaften bleiben lange bedürftig. IAB Short Report 5/2009, Nuremberg

Hasnain Z, Manning N, Pierskalla JH (2012) Performance-related Pay in the Public Sector, Policy Research Working Paper 6043

Hendra R, Riccio JA, Dorsett R, Greeberg DH, Kngiht G, Phillips J, Robins PK, Vegeris S, Walter J, Hill A, Ray K, Smith J

(2011) Breaking to low pay, no-pay cycle: Final evidence from the UK Employment Retention and Advancement (ERA) demonstration, Department for Work and Pensions, Research Report No. 765

Heyer G, Koch S, Stephan G, Wolff J (2012) Evaluation der aktiven Arbeitsmarktpolitik: Ein Sachstandsbericht für die Instrumentenreform 2011. J Labour Market Res 45:41-62. doi:10.1007/s12651-012-0099-5

Institut für Sozialforschung und Gesellschaftspolitik (ISG)/Institut für Arbeitsmarkt- und Beruffforschung (IAB) (2014) Wissenschaftliche Begleitung und Evaluation des Programms "Modellhafte Entwicklung eines sozialen Arbeitsmarktes'Passiv-Aktiv-Tausch'(PAT)". 1. Interim Report, 27 May 2014, Cologne/Nuremberg

Jacobi L, Kluve J (2006) Before and After the Hartz Reforms: The Performance of Active Labor Market Policy in Germany, IZA Discussion Paper No. 2100

Jerger J, Pohnke C, Spermann A (2001) Gut betreut in den Arbeitsmarkt? Eine mikroökonometrische Evaluation der Mannheimer Arbeitsvermittlungsagentur. Mitt Arbeitsmarkt Beruffforsch 34(4):567-576

Junankar PN (Raja) (2011) The Global Economic Crisis: Long-Term Unemployment in the OECD. IZA Discussion Paper No. 6057, Bonn

Kaltenborn B, Kaps P (2012) Einbeziehung der kommunalen Leistungen in die Zielsteuerung des SGB II, Bericht an das Bundesministerium für Arbeit und Soziales. BMAS Forschungsbericht 434, Bonn

Kluve J (2013) Aktive Arbeitsmarktpolitik: Maßnahmen, Zielsetzungen, Wirkungen. Sachverständigenrat zur Begutachtung der gesamtwirtschaftlichen Entwicklung. Arbeitspapier 07/2013, Sachverständigenrat zur Begutachtung der gesamtwirtschaftlichen Entwicklung, Wiesbaden

Knabe A, Rätzel S, Schöb R, Weimann J (2010) Dissatisfied with life but having a good day: Time-use and well-being of the unemployed. Econ J 120:867-889. doi:10.1111/j.1468-0297.2009.02347.x

Knuth M, Stegmann T, Zink L (2014) Die Wirkungen des Bundesprogramms "Perspektive 50plus" - Chancen für ältere Langzeitarbeitslose. IAQ-Report 2014-01, University of Duisburg-Essen, Duisburg/Essen

Koch S, Kupka P, Steinke J (2009) Aktivierung, Erwerbstätigkeit und Teilhabe: Vier Jahre Grundsicherung für Arbeitsuchende. IAB Library 315, Nuremberg

Koller-Bösel L, Lietzmann T, Rudolph H (2014) Bestand und Turnover in der Grundsicherung. WSI Mitteilungen 6(2014):450-458

Königs S (2014) State dependence in social assistance benefit receipt in Germany before and after the Hartz Reforms. In: Carcillo S, Immervoll H, Jenkins SP, Königs S, Tatsiramos K (eds) Safety Nets and Benefit Dependence, vol 39, Research in Labor Economics. Emerald Group Publishing Limited, Bingley, pp 107-150 
Kroft K, Lange F, Notowidigdo MJ (2013) Duration dependence and labor market conditions: Evidence from a field experiment. QJE 128(3):1123-1167

Lechner M, Sari N (2014) Labor Market Effects of Sports and Exercise: Evidence froim Canadian Panel Data. IZA Discussion Paper No. 7931

Martin JP (2015) Activation and active labour market policies in OECD countries: stylized facts and evidence on their effectiveness. IZA Journal of Labor Policy 4:4. Bonn. http://www.izajolp.com/content/pdf/s40173-015-0032-y.pdf. Accessed 14 May 2015

McVicar D (2014) The impact of monitoring and sanctioning on unemployment exit and job-finding rates. IZA World of Labor: 49, Bonn. http://wol.iza.org/articles/impact-of-monitoring-and-sanctioning-on-unemployment-exit-and-jobfinding-rates. Accessed 16 April 2015

Michalopoulos C (2005) Does Making Work Pay Still Pay?: An Update on the Effects of Four Earnings Supplement Programs on Employment, Earnings, and Income. MDRC, New York

Ministry for Social Affairs Baden-Wuerttemberg (2012) Press release 19/11/2012

OECD (2014) OECD Employment Outlook 2014. Publishing, OECD

Rinne U, Zimmermann KF (2013) Is Germany the north star of labor market policy? IMF Economic Review 61(4):702-729. doi:10.1057/imfer.2013.21

Robins PK, Michalopoulos C, Foley K (2008) Are two carrots better than one? The effects of adding employment service to financial incentive programs for welfare recipients. Ind Labor Relat Rev 61(3):410-423

Rosholm M (2014) Do case workers help the unemployed?, IZA World of Labor: 72, Bonn. http://wol.iza.org/articles/ do-case-workers-help-the-unemployed. Accessed 16 April 2015

Sachverständigenrat zur Begutachtung der gesamtwirschaftlichen Entwicklung (2006) Arbeitslosengeld II reformieren: Ein zielgerichtetes Kombilohnmodell. Expertise im Auftrag des Bundesministers für Wirtschaft und Technologie, Wiesbaden

Solow RM (1998) Guess who likes welfare (Lecture 1), Guess who pays for workfare (Lecture 2). In: Gutman A (ed) Work and welfare, Princeton, pp. 3-43

Spermann A (2014) Using Online Platforms for Competence Tests: A Component of the Demographic Policy of Germany, IZA Policy Paper No. 83

Spermann A, Strotmann H (2005): The Targeted Negative Income Tax (TNIT) in Germany: Evidence from a Quasi Experiment, ZEW Discussion Paper No. 05-68

Van den Berg GJ, Hofmann B, Stephan G, Uhlendorff A (2014) Eingliederungsvereinbarung - Vermittlungsfachkräfte halten mehr Spielraum für sinnvoll, IAB-Kurzbericht 22/2014, Nuremberg

Winkelmann L, Winkelmann R (1998) Why are the unemployed so unhappy? Evidence from panel data. Economica 65:1-15. doi:10.1111/1468-0335.00111

Winterhager H, Heinze A, Spermann A (2006) Deregulating job placement in Europe: A microeconomic evaluation of an innovative voucher scheme in Germany. Lab Econ 13:505-517

Wolff J, Stephan G (2013) Subsidised work before and after the German Hartz reforms: design of major schemes, evaluation results and lessons learnt. IZA J Labor Policy 2:16. doi:10.1186/2193-9004-2-16

\section{Submit your manuscript to a SpringerOpen ${ }^{\circ}$ journal and benefit from:}

- Convenient online submission

Rigorous peer review

- Immediate publication on acceptance

- Open access: articles freely available online

- High visibility within the field

Retaining the copyright to your article 